\title{
RISK MANAGEMENT IN JZR DEVELOPMENT PROGRAMME
}

\author{
Adam GUMIŃSKI ${ }^{*}$, Artur DYCZKO ${ }^{2}$, Rafał RYCHTER $^{3}$, Adam BOSOWSKI $^{4}$ \\ ${ }^{1}$ Silesian University of Technology, Faculty of Organization and Management; adam.guminski@polsl.pl, \\ ORCID: 0000-0001-8250-7101 \\ ${ }^{2}$ Jastrzębska Coal Company Ltd.; ORCID: 0000-0002-5613-0395 \\ ${ }^{3}$ Jastrzębska Coal Company Ltd.; ORCID: 0000-0003-4815-7229 \\ ${ }^{4}$ Jastrzębska Coal Company Ltd.; ORCID: 0000-0001-6631-0608 \\ * Correspondence author
}

Purpose: The main purpose of undertaken research was the analysis of risk management, especially, the adequate identification of risk factors and planning actions reducing their adverse effects. Ongoing monitoring of these risks is crucial to achieve the effects of investment project implementation.

Design/methodology/approach: The authors present the research results concerning risk management in JZR (Jastrzębskie Zakłady Remontowe) Development Programme. Risk is an immanent element in the activity of a production company. Therefore, it requires an adequate approach in order to achieve the maximization of economic effects. The JZR Development Programme is a good example of the complexity of processes that should be taken into account in risk management of an investment project.

Findings: The specificity of machine building enterprises determines the scope and scale of the necessary activities for efficient and effective risk management. The main scientific problem focuses on the analysis and categorization of risk factors. As a result, the authors determine appropriate responses to identified risks in the JZR Development Programme.

Originality/value: The development of risk response is crucial for the success of the analysed project. These actions allow to reduce the negative impact of risk factors on the project's timeliness, project's budget as well as economic and technical-technological effects. Another necessary process within risk management is constant monitoring of a project implementation in accordance with the adopted methodology, which enables current updating of emerging new threats to the project implementation and developing necessary actions to minimize the threats.

Keywords: risk management, machine-building enterprise, project management, investment process, new product.

Category of the paper: research paper. 


\section{Introduction}

An enterprise executes many investment projects, which are risky or endangered with the failure of achieving planned objectives. However, on the other hand, it is an investment process and risks associated with it which are key determinants of civilization development. Risk should be treated as an extremely important factor in a business management process. Risk is a natural and widespread phenomenon that occurs in all areas of business activity (human resources management, investment management, fixed asset management, logistics, financial management, production management). Such an approach to risk means that it cannot be completely eliminated out of the business.

The developmental project launched under the name of the JZR (Jastrzębskie Zakłady Remontowe) Development Programme is an insourcing process within the JSW Capital Group, i.e. direct supplies of products to coalmines whose production will be carried out within the capital group. The JZR Development Programme is aimed at achieving developmental objectives on both JZR and JSW sides, among which the production of 5 products which can be considered as crucial i.e. scraper conveyor elements, main pipelines, belt conveyor rollers, suspended track rails and sections of powered roof support.

The main purpose of undertaken research was the analysis of risk management concerning the JZR Development Programme, which is a development investment carried out by a production and service company i.e. JZR Ltd. The company can be assigned to a machine building sector. The main scientific problem focuses on the analysis and categorization of risk factors in the JZR Development Programme. The authors, as a result of the study, determine key actions to minimize negative effects of risks within the JZR Development Programme.

\section{Risk management in production enterprise's activity}

Risk management is of a significant importance issue studied by many authors (Hottenstein and Dean, 1992; Jonek-Kowalska, 2019; Jonek-Kowalska, 2018; Matuszewski, 1992; Teczke, 1999; Thamhain, 2013; Trzeciak and Spałek, 2016; Williams, et al, 2002; Wodarski, 2009). Definitions of a risk that appear in the literature reflect its negative economic significance, e.g. the risk is "the hazard of failure to achieve the goal (achieving a worse result, a loss etc.)" or "the probability of negative event, ... the probability of events independent of the acting entity which cannot be accurately predicted and which cannot be fully prevented, but which by reducing positive results and/or by increasing costs - would take away the effect of completely or partially trait of effectiveness, advantage and efficiency" (Pszczółkowski, 1978). 
In project management methodology, e.g. PMBoK 2013 (PMBOK Guide), risk is defined as the probability of occurrence of a phenomenon or activity that may have a negative or positive impact on the whole project or its individual parts (Trocki, 2012).

S. Nahotko defines risk management as a "system of methods and actions aimed at reducing the degree of risk impact on the functioning of an economic entity and making optimal decisions for this purpose" (Nahotko, 2001). C.A. Wiliams, M.L. Smith and P.C. Young treat risk management as "broadly understood management actions whose task is to identify and assess risks and to fight against its causes and impact on the organization" (Williams, 2002).

Production companies are more sensitive to macroeconomic factors and therefore have less influence on their active shaping, which in turn results in a higher risk level of their activity (Dohn, et al., 2011). An important source of risk is the indeterminacy of parameters characterising business activity (a large number of parameters, their heterogeneity, multistability and randomness of changes) (Dohn, et al., 2012; Dohn, et al., 2013).

The enterprises of machine building industry have specific features, which generate an increased risk level in the activities of these enterprises, among which should be distinguished (Dohn, et al., 2011; Dohn, et al., 2012):

- production processes have a tooling and assembly character of high complexity, requiring advanced technology and technical facilities,

- a significant share of unit production requires a stable technological and construction base for the execution of contracts, mainly highly qualified engineering and technical staff as well as IT infrastructure,

- effectiveness of functioning of machine building enterprises depends on appropriate knowledge about suppliers and co-operators,

- due to high uncertainty and variability in the use of production capacities, there is a need to maintain surpluses in the technical infrastructure (machines, equipment) while balancing the staffing needs in relation to the contract portfolio being realized,

- implementing favourable contracts requires a careful analysis of many parameters depending on macroeconomic and microeconomic conditions.

Analysing risk management processes, four basic stages can be given (Teczke, 1999):

- risk identification, which consists of determining the maximum number of possible sources of risks and their characteristics,

- risk assessment, under which identified risk sources are assigned the probability of occurrence and the range of possible losses related to the occurrence of a given risk source in company's activity,

- activities reducing risk that involve the need to select tools resulting in risk prevention or reducing its negative effects, 
- risk control, which involves assessing the effectiveness and efficiency of the undertaken risk activities and provides information on required modifications and improvements to the earlier stages of risk management.

The scope and scale of risk are the result of specific conditions of the activities of manufacturing enterprises. The implementation of individual contracts to order determines an increased level of risk in the operations of these enterprises (Dohn, et al., 2012; Dohn, et al., 2013). Therefore, in the management processes in these enterprises, it is necessary to consider the risk aspect, which for decision makers means the necessity of predicting different future scenarios and determining risk factors as well as the scope and scale of their potential negative impact on the activity of these enterprises and seeking active actions to mitigate adverse effects.

The identification of risk factors should include their assignment to a risk category. Risk categories should be well defined and should correspond to typical sources of risks for a given industry and the specificity of production company's activity. The most common risk categories are: technical risks, project management risks, organizational risks and macroeconomic risks.

The risk identification tools and techniques commonly used are:

- documentation reviews (e.g. a detailed contract implementation plan),

- information gathering techniques (brainstorming, Delphi technique, questionnaires, SWOT analysis),

- checklists (to speed up and simplify the identification of risk factors),

- analysis of project's assumptions,

- techniques based on diagrams (cause-effect diagrams, system block diagrams, influence diagrams).

An important step in risk management of individual contracts is to determine actions that reduce their adverse effects. The following actions can be used for this purpose to respond to the risk (PMBOK Guide, 2013):

- avoiding the risk focused on changes that eliminate a given risk (e.g. clarifying requirements, improving communication, commissioning additional specialist analyses),

- transfer of risk consisting in transferring the negative effects of risk to another entity (the best-known form is insurance),

- risk mitigation by reducing the probability and/or effect of a risk to an acceptable level,

- accepting the risk focused on not taking any action (passive acceptance) or developing an emergency plan (active acceptance). 


\section{The characteristics of JZR Development Programme as a key developmental investment}

JZR Ltd. is a company, which since 1993 has provided facilities for renovation and modernization of machinery and equipment used in production plants of JSW Capital Group. The concept of the JZR Development Programme was prepared in response to the needs of JSW, which strives to ensure stable supplies of machinery and equipment necessary in ongoing operations of the company's coalmines. The main goal of the JZR Development Programme is to expand production and renovation activities in the scope of delivering ready products to JSW production plants. The key assumptions of the JZR Development Programme were defined as follows:

- the target production: 5 products, i.e. armoured conveyor elements, main pipelines, belt conveyor rollers, suspended track rails and sections of powered roof support (presented in table 1),

- location: Suszec Community,

- additional employment: about 200 skilled workers, mainly welders and CNC operators,

- using specialized machines and devices, mainly CNC machines and welding robots, to optimize the demand for new employees,

- estimated capital expenditures: $95 \mathrm{mln}$ PLN (modernization/construction of facilities, including production halls and their equipment),

- sources of financing: capital from JSW Capital Group with the contribution of the land and production halls in the area of Suszec, own funds of JZR Ltd. and co-financing deriving from operational programmes,

- time range: the start of production of the first 4 products - August 2020, start of the production of powered roof supports - January 2022.

Table 1.

The list of planned products in JZR Development Programme

\begin{tabular}{|l|c|c|c|}
\hline No. & The planned product & The visualisation of a product & The start of production \\
\hline 1. & Armoured conveyor elements & & August 2020 \\
\hline 2. & Mainpipelines & & \\
\hline
\end{tabular}


Cont. table 1 .

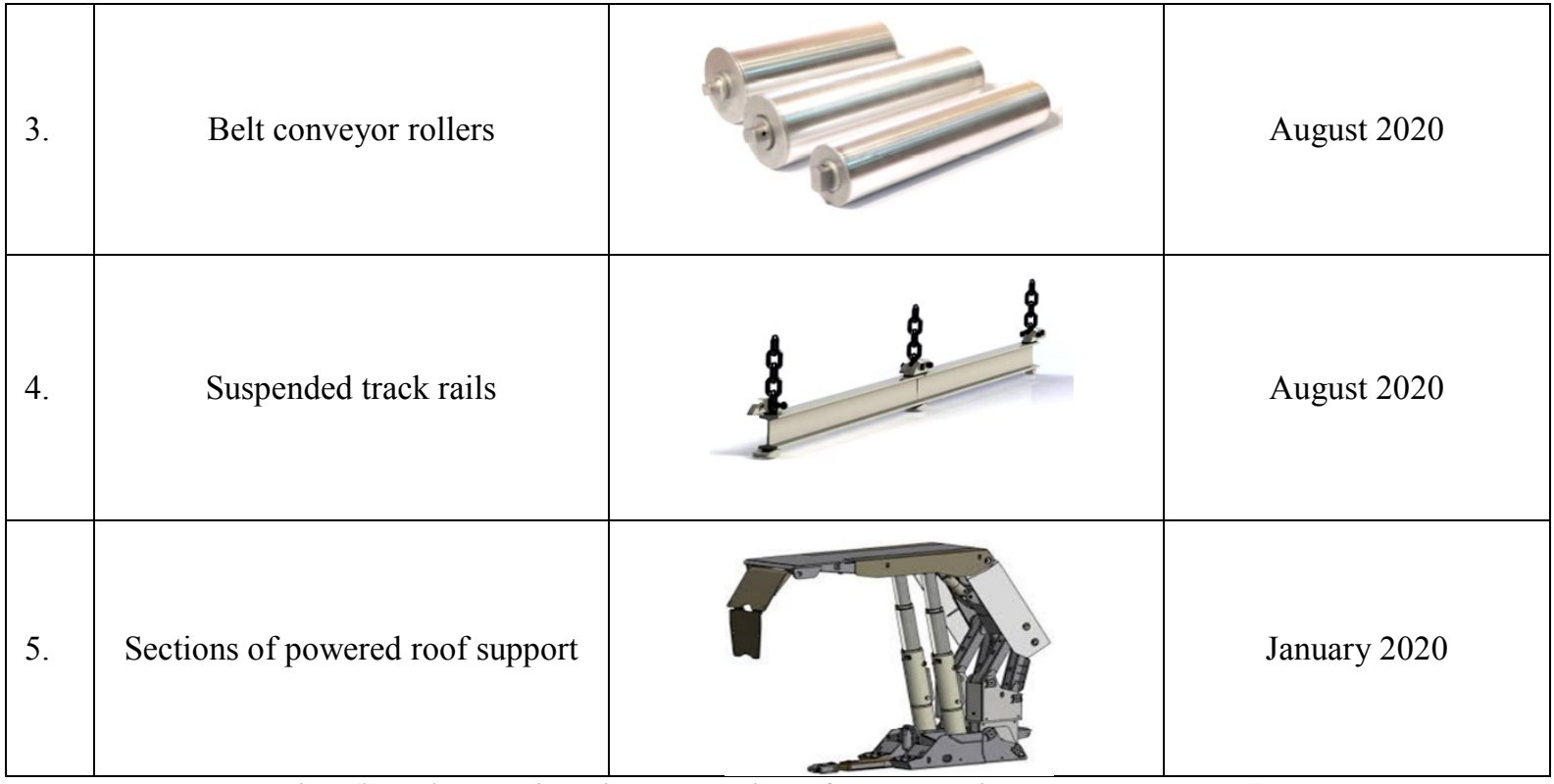

Source: own preparation (based on project documentation of JZR Development Programme).

The JZR Development Programme's Project Team consists of the representatives of JZR Ltd. JSW Capital Group and JSW Innovations Ltd.

Achieving the assumed objectives of the JZR Development Programme is going, in the medium-term perspective, to enable strengthening the competitiveness level and increasing the market value of both JZR Ltd. and JSW Capital Group.

\section{Risk management processes in JZR Development Programme}

Risk management of companies in the JSW Capital Group the operational and investment activities is carried out in accordance with the ISO 31000, COSO II and FERMA standards in the frame of the Enterprise Risk Management System (ERM). The most important risk management processes in the ERM system include:

- identification and risk assessment,

- development and implementation of risk response plans,

- monitoring and reporting on the effectiveness of risk management.

The identification of risk factors is the first stage in risk management. The appropriate analysis of risk factors along with their categorization is extremely important in the aspect of minimizing the negative impact of risk on business activity of the company. The lack of sufficient knowledge about the existing internal and external threats multiplies the negative impact on the efficiency of enterprises. This is particularly important for enterprises of the machine building industry in a current dynamically changing economic situation. 
Considering the complexity of the analysed investment project, the project team of JZR Development Program in the initial phase of project's implementation paid much attention to the aspects of risk management. He determined main risk categories, identified risk factors, and then proposed actions to reduce the negative effects of existing risks. While identifying risk factors, the potential threats to project's timeliness, project's budget and achieving assumed economic and technical-technological effects were taken into account. The analyses undertaken allowed to determine the following main risk categories:

- design and construction works,

- technical and technological hazards,

- human resources,

- economic hazards.

Table 2 presents main risk categories, identified risk factors along with the planned activities reducing their negative impact on the implementation of JZR Development Programme. The table includes both significant standard and specific risk factors related to the implementation of JZR Development Programme.

The biggest threat (the highest level of risk) is related to factors in the category of design and construction works, which may lead to a significant delay in the project finalization, as well as exceeding the assumed budget, and resulting in reducing economic profitability of the analysed investment project. Therefore, actions reducing risks in this category are of key importance for ensuring the success of JZR Development Programme.

Table 2.

The list of risk factors and actions reducing their negative impact in JZR Development Programme

\begin{tabular}{|c|c|c|c|}
\hline No. & Risk category & Risk factor & Actions reducing risk \\
\hline \multirow{5}{*}{1.} & \multirow{5}{*}{$\begin{array}{l}\text { Design and } \\
\text { construction } \\
\text { works }\end{array}$} & $\begin{array}{l}\text { problems in the implementation of } \\
\text { project work }\end{array}$ & $\begin{array}{l}\text { launching auctions for design works, } \\
\text { monitoring of ongoing works }\end{array}$ \\
\hline & & $\begin{array}{l}\text { problems in the implementation of } \\
\text { construction and assembly works }\end{array}$ & $\begin{array}{l}\text { launching auctions for construction and } \\
\text { assembly works, monitoring of ongoing } \\
\text { works }\end{array}$ \\
\hline & & limited access to design companies & appropriate auction entries \\
\hline & & $\begin{array}{l}\text { limited access to construction and } \\
\text { assembly companies }\end{array}$ & appropriate auction entries \\
\hline & & $\begin{array}{l}\text { untimely delivery of machinery and } \\
\text { equipment necessary to start production }\end{array}$ & $\begin{array}{l}\text { launching auctions for supplies of } \\
\text { machinery and equipment }\end{array}$ \\
\hline \multirow{4}{*}{2.} & \multirow{4}{*}{$\begin{array}{l}\text { Technical and } \\
\text { technological } \\
\text { issues }\end{array}$} & $\begin{array}{l}\text { difficulties in developing a target } \\
\text { production program compatible with the } \\
\text { assumptions of JZR Development } \\
\text { Programme }\end{array}$ & $\begin{array}{l}\text { launching the work of technical and } \\
\text { technological team }\end{array}$ \\
\hline & & $\begin{array}{l}\text { the lack of construction documentation } \\
\text { of new products }\end{array}$ & $\begin{array}{l}\text { launching the work of technical and } \\
\text { technological team }\end{array}$ \\
\hline & & negative results of tests of new products & changes in product prototypes \\
\hline & & $\begin{array}{l}\text { unsatisfactory level of research and } \\
\text { development }\end{array}$ & $\begin{array}{l}\text { cooperation with research and } \\
\text { development centres and universities }\end{array}$ \\
\hline
\end{tabular}


Cont. table 2.

\begin{tabular}{|c|c|c|c|}
\hline \multirow{4}{*}{3 . } & \multirow{4}{*}{$\begin{array}{l}\text { Human } \\
\text { resources }\end{array}$} & limited access to external specialists & $\begin{array}{l}\text { cooperation with research and } \\
\text { development centres and universities }\end{array}$ \\
\hline & & $\begin{array}{l}\text { difficulties in acquiring new qualified } \\
\text { employees with strictly defined } \\
\text { competences }\end{array}$ & $\begin{array}{l}\text { multi-stage recruitment of employees, } \\
\text { changes in a motivation system }\end{array}$ \\
\hline & & $\begin{array}{l}\text { insufficient level of technical and } \\
\text { economic competences of JZR } \\
\text { employees }\end{array}$ & $\begin{array}{l}\text { training and professional development of } \\
\text { employees }\end{array}$ \\
\hline & & $\begin{array}{l}\text { increased needs for employees handling } \\
\text { contracts for the supply of products to } \\
\text { JSW coalmines }\end{array}$ & $\begin{array}{l}\text { recruitment of new employees with } \\
\text { specific technical and economic } \\
\text { competences, changes in a motivation } \\
\text { system }\end{array}$ \\
\hline \multirow{9}{*}{4.} & \multirow{9}{*}{$\begin{array}{l}\text { Economic } \\
\text { hazards }\end{array}$} & $\begin{array}{l}\text { obtaining necessary corporate approvals, } \\
\text { including contribution of grounds and } \\
\text { production halls }\end{array}$ & monitoring of corporate procedures \\
\hline & & $\begin{array}{l}\text { limited stability of the activity of } \\
\text { suppliers of materials and components } \\
\text { for production }\end{array}$ & risk acceptance \\
\hline & & $\begin{array}{l}\text { implementation of contracts to order for } \\
\text { selected products for JSW coalmines }\end{array}$ & $\begin{array}{l}\text { negotiation of contracts' parameters for } \\
\text { JSW }\end{array}$ \\
\hline & & $\begin{array}{l}\text { limited own funds for developing JZR } \\
\text { production potential }\end{array}$ & $\begin{array}{l}\text { launching the procedure for obtaining } \\
\text { additional funds within the JSW Capital } \\
\text { Group }\end{array}$ \\
\hline & & $\begin{array}{l}\text { limited trade margin for products } \\
\text { dedicated to JSW coalmines }\end{array}$ & $\begin{array}{l}\text { negotiations of contracts' parameters for } \\
\text { JSW }\end{array}$ \\
\hline & & $\begin{array}{l}\text { the progressive monopolisation of the } \\
\text { market by Famur Company for target } \\
\text { products manufactured within the JZR } \\
\text { Development Programme }\end{array}$ & risk acceptance \\
\hline & & $\begin{array}{l}\text { difficulties in business activity of } \\
\text { potential contractors }\end{array}$ & risk acceptance \\
\hline & & $\begin{array}{l}\text { the great dependence on the situation of } \\
\text { the main recipient of JZR Development } \\
\text { Programme products in the context of } \\
\text { changes in a hard coal sector }\end{array}$ & risk acceptance \\
\hline & & $\begin{array}{l}\text { changes in legal conditions for JZR } \\
\text { activity }\end{array}$ & $\begin{array}{l}\text { monitoring of changes and analysing } \\
\text { legal effects on JZR activities }\end{array}$ \\
\hline
\end{tabular}

Source: own preparation.

\section{Conclusions}

The undertaken studies in the field of risk management of JZR Development Programme allow the following conclusions:

1. The JZR Development Programme is a priority development investment within JSW Capital Group, which enables stable supplies of products manufactured by JZR. The process of insourcing the supply of selected products will result in reducing the economic risk of JSW's activity. 
2. The first and key stage of risk management in JZR Development Program is the identification of risk factors along with their categorization taking into account the specificity of JZR functioning as a machine building enterprise.

3. The development of risk response is crucial for the success of the analysed project. These actions allow to reduce the negative impact of risk factors on the project's timeliness, project's budget as well as economic and technical-technological effects. Another necessary process within risk management is constant monitoring of a project implementation in accordance with the adopted methodology, which enables current updating of emerging new threats to the project implementation and developing necessary actions to minimize the threats.

\section{References}

1. Dohn, K., Gumiński, A., and Zoleński, W. (2011). Assumptions for the creation of a system supporting knowledge management in an enterprise of mechanical engineering industry. In: Proceedings of Information systems in management XIII. Business intelligence and knowledge. WULS Press, pp. 19-27.

2. Dohn, K., Gumiński, A., and Zoleński, W. (2012). Uwarunkowania decyzji o realizacji kontraktu w przedsiębiorstwie budowy maszyn. Zeszyty Naukowe Uniwersytetu Szczecińskiego. Ekonomiczne Problemy Ustug, vol. 87, pp. 642-651.

3. Dohn, K., Gumiński, A., Matusek, M., and Zoleński, W. (2013). Model wspomagania zarzadzania w zakresie zarzadzania wiedza w polskich przedsiębiorstwach budowy maszyn. Warszawa: Difin.

4. Guide to the Project Management Body of Knowledge (PMBOK Guide) (2013). Warszawa: Project Management Institute, MT\&DC.

5. Hottenstein, M.P., and Dean, J.W. (1992). Managing Risk in Advanced Manufacturing Technology. California Management Review, vol. 34(4), doi:10.2307/41166706.

6. Jonek-Kowalska, I. (2018). Consolidation as a risk management method in the lifecycle of a mining company: a novel methodological approach and evidence from the coal industry in Poland. Resource Policy, vol. 60, pp. 169-177, doi: 10.1016/j.resourpol.2018.12.014.

7. Jonek-Kowalska, I. (2019). Identyfikacja, ocena i przeciwdziałanie ryzyku operacyjnemu w przedsiębiorstwie górniczym. In: M. Turek (Ed.), Zarządzanie w przedsiębiorstwie górniczym. Wybrane zagadnienia (pp. 193-282). Gliwice: Wydawnictwo Politechniki Śląskiej.

8. Matuszewski, A. (1996). Metoda analityczna oceny ryzyka podejmowanych przedsięwzięć rozwojowych. Przemyst Drzewny, vol. 8, pp. 2-5. 
9. Nahotko, S. (2001). Ryzyko w działalności gospodarczej przedsiębiorstw. Bydgoszcz: Wydawnictwo OPO1.

10. Pszczółkowski, T. (1978). Mała encyklopedia prakseologii i teorii organizacji. WrocławWarszawa-Kraków-Gdańsk: Ossolineum.

11. Teczke, J. (1999). Zarządzanie przedsięwzięciami zwiększonego ryzyka. Kraków: PAN.

12. Thamhain, H. (2013). Managing Risks in Complex Projects. Project Management Journal, vol. 44(2), doi: 10.1002/pmj.21325.

13. Trocki, M. (2012). Nowoczesne zarzadzanie projektami. Warszawa: PWE.

14. Trzeciak, M., and Spałek, S. (2016). Zarządzanie ryzykiem w ramach metodyk tradycyjnych oraz zwinnych w zarządzaniu projektami. Zeszyty Naukowe Politechniki Ślaskiej Seria: Organizacja i Zarządzanie, vol. 93, pp. 483-492.

15. Wiliams, C.A., Smith, M.L., and Young, P.C. (2002). Zarzadzanie ryzykiem a ubezpieczenia. Warszawa: PWN.

16. Wodarski, K. (2009). Zarzadzanie ryzykiem $w$ procesie planowania strategicznego w górnictwie węgla kamiennego. Gliwice: Wydawnictwo Politechniki Śląskiej. 